msh-mss Mathématiques et sciences humaines

193 | Printemps 2011

Varia

\title{
A propos de la notion de rôle dans l'analyse des relations sociales
}

About the concept of role in the analysis of social relations

\section{Alain Degenne}

\section{(2) OpenEdition}

1 Journals

Édition électronique

URL : http://journals.openedition.org/msh/11969

DOI : $10.4000 / \mathrm{msh} .11969$

ISSN : 1950-6821

Éditeur

Centre d'analyse et de mathématique sociales de l'EHESS

\section{Édition imprimée}

Date de publication : 15 janvier 2011

Pagination : $37-45$

ISBN : 09876936

ISSN : 0987-6936

\section{Référence électronique}

Alain Degenne, "A propos de la notion de rôle dans l'analyse des relations sociales », Mathématiques et sciences humaines [En ligne], 193 | Printemps 2011, mis en ligne le 01 juin 2011, consulté le 23 juillet 2020. URL : http://journals.openedition.org/msh/11969; DOI : https://doi.org/10.4000/msh.11969

Ce document a été généré automatiquement le 23 juillet 2020

(c) École des hautes études en sciences sociales 


\title{
A propos de la notion de rôle dans l'analyse des relations sociales
}

\author{
About the concept of role in the analysis of social relations
}

\section{Alain Degenne}

\section{RÉSUMÉS}

La notion de rôle, en sociologie est traditionnellement définie comme un ensemble de prescriptions comportementales associées à une position dans la société. Le point de vue interactionniste permet de renouveler cette vision en faisant découler les rôles sociaux d'une analyse des interactions entre les individus. L'analyse formelle des graphes d'interactions permet de mettre en œuvre plusieurs définitions des rôles liées à l'idée d'équivalence de position entre les individus. L'équivalence régulière se révèle particulièrement intéressante.

In sociology the concept of role is traditionally defined as a set of behavioural requirements associated with a position in the society. The interactionist perspective can renew this vision by deducing the social roles of an analysis of interactions between individuals. The formal analysis of interaction graphs can implement multiple definitions of roles related to the idea of the equivalence of positions between individuals. The regular equivalence is particularly interesting.

\section{INDEX}

Mots-clés : équivalence régulière, rôle, sociologie

Keywords : regular equivalence, role, sociology 
AUTEUR

ALAIN DEGENNE

Aciennement directeur de recherche au Centre Maurice Halbwach, EHESS, adegenne@wanadoo.fr 